\title{
PhDs leave the ivory tower
}

\section{UK doctoral training centres prepare students to run a lab - or work outside academia.}

\section{BY DANIEL CRESSEY}

$\mathrm{N}$ ot so long ago, doctoral students were viewed as the galley slaves of the scientific world, spending long hours in the lab for a meagre wage and the promise that three precious letters - $\mathrm{PhD}$ - would eventually burnish their name.

But that attitude has changed. Recognizing that few graduates spend their entire careers at the bench, research funders and education authorities are reshaping the $\mathrm{PhD}$ to train students in non-science skills such as networking as well as research. One of the most radical expositions of this philosophy is unfolding in the United Kingdom, where $\mathrm{PhD}$ students are increasingly coming out from under the wing - and the shadow - of a PhD supervisor. Instead of being trained individually in one academic's research group, they are being taught in cohorts in a doctoral training centre (DTC) - a university-based hub focusing on highly specific areas, such as chemical synthesis or nuclear fission. DTC courses last four years rather than the three of a standard UK $\mathrm{PhD}$, and include formal coursework as well as lab experience.

Britain's main physical-sciences funding body, the Engineering and Physical Sciences Research Council (EPSRC), has opened more than 50 DTCs, most of them in 2009. This year, for the first time, it has funded more students through centres than through research grants (see 'Training in transition'). Some academics worry that the centre-based approach will squeeze blue-sky research out of $\mathrm{PhD}$ programmes

"The world of research has changed, is changing and will continue to change. Training centres are a way to respond to that." - and deprive senior scientists of eager assistants. But delegates gave positive reviews of the DTC model last month at a meeting in London

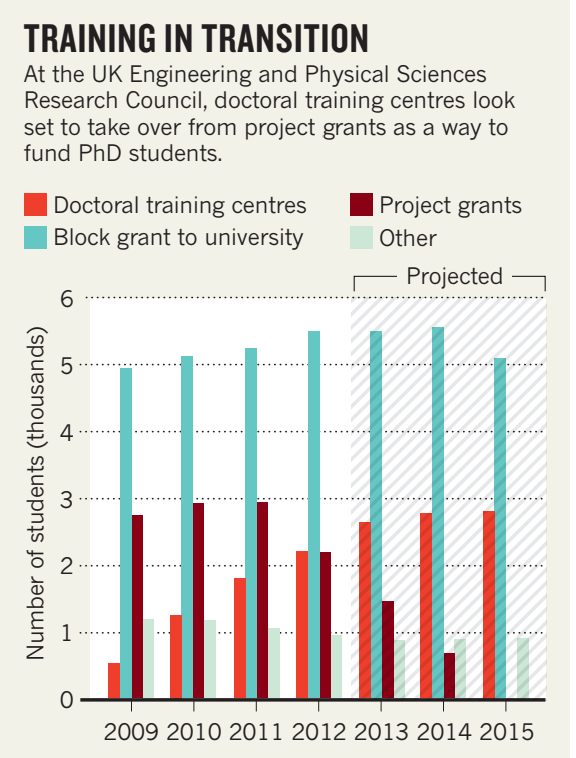

organized by Vitae, a government-funded group based in Cambridge that pushes for improved researcher training.

"The world of research is changing, has changed and will continue to change. I see centres as being a way that we respond to that," says Neil Viner, associate director of the EPSRC. Other British funding agencies are now following the EPSRC's lead, and several funders abroad are either considering adopting similar systems, or already working on it.

Rudiger Woscholski, deputy director of Imperial College London's Institute of Chemical Biology DTC, says that the centre's students are far better equipped than traditional $\mathrm{PhD}$ students to collaborate with other labs and with industry. Arieh Iserles, co-director of the Cambridge Centre for Analysis at the University of Cambridge, adds that the four-year DTC programmes also leave graduates better prepared for postdoctoral work.

Similar schemes have been launched by other UK research councils, such as the Biotechnology and Biological Sciences Research Council (BBSRC), which sponsors doctoral training partnerships in which partner institutions receive grants to coach cohorts of students for four years. Although the partnerships do not create centres as such, they are designed to build a structured doctoral training environment. Celia Caulcott, director of innovation and skills at the BBSRC, points out that the councils are also keeping other funding routes open. Students can still pursue focused research-based degrees, she says, and universities that fail to become partners can still maintain $\mathrm{PhD}$ programmes funded by block grants based on their research income.

Other nations are closely watching Britain's PhD reform. Lidia Borrell-Damian, senior programme manager for research and innovation at the European University Association in Brussels, says that there has been a Europewide move towards more formalized $\mathrm{PhD}$ training and stronger links with industry. Germany, for example, has begun to shift its $\mathrm{PhD}$ programmes to a model that increases institutional oversight and aims to prepare students for the wider world of work (see Nature 472, 276-279; 2011). The United Kingdom, adds Borrell-Damian, is a leader in many other innovative aspects of $\mathrm{PhD}$ reform, such as cosupervision with an academic and an external supervisor.

"In the years to come almost all universities in Europe will have to some extent a graduate school or a doctoral school," she says. "That is unstoppable." -

\section{CORRECTION}

The News story 'Chemistry's web of data expands' (Nature 483, 524; 2012) wrongly stated that Antony Williams led the effort to clean up structures on Wikipedia. Although he took part in the effort, he did not lead it.

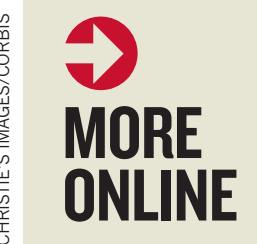

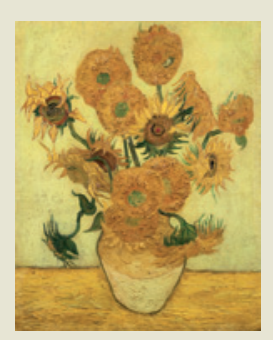

\section{OTHER NEWS}

- Moving towards a universal flu vaccine go.nature.com/vig8eb - Humans have been cooking with fire for one million years go.nature.com/ cfwnav

- Ratio rethink will adjust rock clocks go.nature.com/nwbdao

\section{PODCAST}

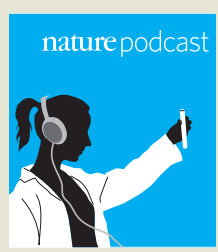

A giant feathered dinosaur, financial incentives for research and a disease that crosses oceans go.nature.com/valwve 